\title{
RESENHAS
}

\section{FRAGMENTOS ÓRFICOS}

GAZZINELLI, Gabriela Guimarães (Org. e trad.). Fragmentos órficos. Belo Horizonte: Ed. UFMG, 2007. 117 p. (Coleção Travessias).

Loraine Oliveira*

lorainebpi@hotmail.com

A tradução dos Fragmentos órficos para a língua portuguesa, ora realizada e organizada por Gabriela Guimarães Gazzinelli, é muito bem vinda, especialmente por dois motivos: primeiro, porque, até então, não dispúnhamos de semelhante edição desses fragmentos para o idioma vernáculo. Segundo, pela própria estrutura do livro. A edição de Gazzinelli tem o mérito de traduzir, organizar e comentar os seguintes fragmentos órficos, oferecendo, assim, um panorama bastante completo do orfismo: 1) o Papiro de Derveni, que possui duas partes, a primeira, de cunho escatológico, e a segunda, composta pela exegese de um poema órfico, ilustrando como se dava a iniciação através da poesia sagrada. 2) o Papiro de Gurob, que instrui sobre rituais órficos. 3) as lâminas de ouro, com conteúdo escatológico, que apresentam recomendações sobre como proceder no Hades. 4) as placas de osso de Ólbia, que parecem ter sido cartões de identificação dos iniciados. O segundo motivo, com efeito, consiste na arquitetura do opúsculo. A autora introduz a tradução dos fragmentos apresentando os "diálogos entre o orfismo e a filosofia antiga". Esses diálogos marcam efetivamente certas escolhas de tradução, assim como reaparecem nas notas, que configuram um fio condutor para a obra. Feita a

* Doutoranda em Filosofia, UFMG, Belo Horizonte, Brasil.

KRITERION, Belo Horizonte, nº 116, Dez/2007, p. 493-496. 
introdução, os fragmentos órficos são traduzidos, e a tradução de cada qual é precedida por um breve prelúdio que informa acerca da datação, do estado do suporte material e do tema. Seguindo, portanto, a estrutura proposta por Gazzinelli, passo à apresentação de cada seção dos Fragmentos órficos.

Ao comentar o diálogo entre o orfismo e a filosofia antiga, Gazzinelli parte de um aspecto fundamental concernente a essa religião de mistério: o orfismo é uma tradição predominantemente escrita. Nisso difere de outras religiões semelhantes, a exemplo dos mistérios de Elêusis, que admitiam a iniciação de escravos e crianças, provavelmente analfabetos. O corpo canônico órfico teria sido constituído por poemas teogônicos, cosmogônicos e escatológicos. Tanto os poemas como suas interpretações foram transmitidos por meio da escrita. Com efeito, o diálogo entre o orfismo e a filosofia provavelmente deve-se ao aspecto literário da religião de mistério. Gazzinelli menciona, por um lado, a interlocução que os mágoi órficos tiveram com textos filosóficos présocráticos no período da formação de algumas doutrinas (século VI-V a.C.). Por outro lado, filósofos contemporâneos ao orfismo, tais como os pitagóricos, Empédocles, Platão e alguns estóicos, referem-se aos poemas e à escatologia dos órficos. Ademais, partes de textos órficos sobreviveram à extinção da religião de mesmo nome. Por conseguinte, junto à transmissão indireta, através de testemunhos, citações e descrições, textos esotéricos possivelmente chegaram a autores como os neoplatônicos, que se interessaram vivamente pelo orfismo. Destarte, a autora discute as relações entre o orfismo e a filosofia antiga com base em três pontos: 1) as doutrinas relativas à alma; 2) a ascese órfica e 3) a exegese dos poemas órficos.

Quanto ao primeiro ponto, Gazzinelli mostra a importância que os mistérios órficos tiveram na formação das idéias gregas sobre a alma. Isso pode ser verificado sob três aspectos que se correlacionam: a imortalidade da alma, a crença em um julgamento após a morte e a crença na metempsicose. Com efeito, enquanto seus antecessores acreditavam que uma sombra de vida aguardava a alma após a morte, os órficos entendiam que os piedosos encontrariam uma vida bem-aventurada, ao passo em que os ímpios teriam uma vida de punições. Claro que isso leva à crença do julgamento após a morte, o que também é fundamental para justificar a vida de ascetismo dos praticantes da religião órfica. Ademais, ao considerar as almas imortais, os órficos igualmente crêem na metempsicose: a alma precisa reencarnar inúmeras vezes para expiar suas impurezas. Todavia, as práticas ascéticas órficas constituiriam o único meio de liberação desse ciclo de vidas. Nesse ponto, Gazzinelli menciona Empédocles, os pitagóricos e, mormente, Platão, a fim de estabelecer o diálogo com a filosofia antiga. Assim, ela traz a lume 
diversas passagens dos diálogos platônicos nas quais se reconhecem essas crenças. Afora isso, comenta o mito de Dioniso Zagreu, que explica a divisão entre corpo e alma para os órficos.

O segundo ponto, acerca da ascese órfica, inicia com um comentário aos preceitos ascéticos. Dentre os mais atestados, encontra-se o vegetarianismo, que parece desdobrar-se em interdição quanto ao uso de produtos animais em geral, como, por exemplo, a lã. A lã parece ter tido uso igualmente restrito entre os egípcios e os filósofos pitagóricos. Além disso, os órficos também não sacrificavam animais em seus cultos, afinal as almas poderiam transmigrar para o corpo de qualquer animal nos ciclos de reencarnação. São mencionados filósofos como Jâmblico e Proclo, por exemplo, que insistiram na afinidade entre órficos e pitagóricos, chegando a afirmar que o próprio Platão recebeu o conhecimento acerca dos deuses dos escritos de uns e outros. A autora ainda indaga acerca das diferenças entre órficos e pitagóricos, considerando que, talvez, a mais relevante seja o fato de os pitagóricos possuírem uma filosofia sistematizada, que explicava o mundo matematicamente, donde a divisão dos adeptos entre acusmáticos e matemáticos.

$\mathrm{O}$ terceiro ponto, concernente às interpretações alegóricas dos poemas órficos, tenta mostrar as semelhanças entre as técnicas exegéticas dos órficos e as dos filósofos antigos. Com efeito, a postura interpretativa dos órficos é compreendida a partir do Papiro de Derveni. Esse documento informa que a leitura e a exegese dos poemas sagrados constituía parte da iniciação órfica. Os poemas eram escritos de modo enigmático com o fito de salvaguardar suas revelações da maioria, isto é, dos não-iniciados. Por conseqüência, o autor do papiro faz uso de diversas técnicas interpretativas, que também são encontradas em certos autores filósofos, como os sofistas, que provavelmente influenciaram a terminologia órfica de interpretação. Dentre as técnicas exegéticas, Gazzinelli elenca a etimologia, a alegoria, as metáforas, os símiles, a polissemia, a homonímia, a sinonímia e a analogia. Ela tenta demonstrar que, quando se trata de interpretar mitos e cosmogonias, técnicas exegéticas semelhantes encontram-se em filósofos como Platão, notadamente no Crátilo, nos estóicos antigos, em Plutarco e em autores neoplatônicos. Assinala, desse modo, uma continuidade entre a religião de mistério e a filosofia grega que lhe é posterior.

Quanto aos textos órficos que podem ser lidos no opúsculo, ainda que mencione testemunhos literários e fontes iconográficas relativas ao orfismo, observa-se que Gazzinelli opta por traduzir os textos esotéricos preservados em papiros e fórmulas mágicas gravadas em amuletos, lançando a suspeita de que eles fizessem parte de rituais e iniciações. O primeiro documento traduzido 
é o Papiro de Derveni. O texto possui uma parte de conteúdo escatológico, e outra, na qual menciona as Rapsódias órficas e sua exegese. Esse papiro, encontrado em uma pira funerária, no ano de 1962, no nordeste da Grécia, foi escrito provavelmente no século IV a.C., sendo, portanto, o mais antigo papiro literário grego de que se tem conhecimento.

O Papiro de Gurob vem a ser o segundo documento traduzido. Data do final do século III a.C., tendo sido localizado no Egito, na cidade de Gurob. Descreve rituais órficos, mas de modo a sugerir um sincretismo entre diferentes cultos de mistério, tais como o orfismo, o dionisismo, os mistérios de Elêusis e os de Sabázio. Esse papiro permite pensar que, ainda no período helenístico, praticavam-se os mistérios órficos. A mesma sugestão decorre de certas lâminas de ouro. Essas eram enterradas com os mortos, contendo indicações de como proceder no Hades. Ademais, nelas encontram-se elementos da escatologia órfica, como a metempsicose, o juízo pós-morte e as reminiscências de vidas anteriores. Constituem o terceiro grupo de documentos traduzidos. Foram encontradas em túmulos datando de V a.C. a II a.C., na Magna Grécia, em Creta e na Tessália. Uma ainda foi localizada em Roma, pertencendo ao século II d.C. Por fim, o último grupo de documentos traduzidos é formado pelas placas de Ólbia. Estas plaquinhas de osso foram descobertas na cidade de Ólbia, situada ao sul da Rússia, onde antes se localizava a colônia grega de Mileto. Três delas, cuja datação remonta ao século V a.C., possuem elementos de interesse para o estudo do orfismo. Observe-se que nelas figura o nome Dion, abreviação de Dioniso, o que permite associar ritos órficos e dionisíacos. As escorreitas traduções de Gazzinelli respeitam as lacunas dos textos gregos, que infelizmente não chegaram aos nossos dias em perfeito estado, sendo os melhores preservados aqueles que se encontram nas placas de ouro. Assim, diante das traduções e auxiliado pela introdução e pelas notas que se fundamentam em vasta bibliografia secundária, o leitor lusófono finalmente tem acesso à doutrina contida nos fragmentos órficos de que dispomos na atualidade. Finalmente, gostaria de observar que a autora disponibiliza as edições dos textos gregos originais no site: <http://www.geocities.com/ ggazzinelli/orfismo>. 